\title{
Is the 'Flying Geese' Paradigm useful to explain advancement in the European Union by means of FDI phenomenon?
}

\author{
Teresa Kamińska \\ University of Gdansk \\ Poland \\ e-mail:t.kaminska@ug.edu.pl
}

\begin{abstract}
The article is the attempt to verify if a long-time existing paradigm of "flying geese" (FGP) might be applied to describe development among the European Union (EU) countries considering foreign direct investment (FDI) flows. Up to now the pattern has been widely used to investigate the process of catching up on growth in the East Asia both in theory and development policy. Although FGP is well known among the Western theorists, it has not been exploited to explain a less advanced economies' pursuit of developed ones, particularly within the EU countries. Therefore, the inquiry is aimed to explain the role of FDI in upgrading the follower's economy in the process of catching up a leader.

The scientific task rests on answering the question whether the newcomers to the EU (Spain and Poland as examples) have changed internal tier of the flying geese formation since their accession, i.e. whether they were able to move to a higher rung of the ladder.
\end{abstract}

Keywords: 'Flying geese' paradigm, foreign trade, FDI, catching up process, European Union, Poland, Spain

JEL classification: F21; F15; O14

\section{INTRODUCTION}

Dynamism of regional integration in last decades 'refreshed' the flying geese model in order to explain the region-wide catching-up process. It is sometimes well-ordered relocation of industries if only backward countries relate themselves with advanced ones along market rationalism (Kasahara, 2013). The flying geese paradigm is assumed to be one of ways to examine economic growth in the European Union.

The scientific purpose of the article is to clarify the catching-up process of growth in newcomers economies to the EU by means of FDI phenomenon in the frame of FGP.

Although the "flying-wild-geese" pattern of industrial development was presented originally by Japanese Kaname Akamatsu in 1930s, it became well-known only in 1960s (Akamatsu, 1962). The FGP has been defined by Akamatsu as “... the development after the less advanced country's economy enters into an economic relationship with the advanced countries" (Akamatsu, 1962, p.11). He describes the phenomenon - from the less developed economy's viewpoint - in three aspects (patterns), i.e. intraindustry (basic type of 
FGP), leading to the interindustry in a particular country, and effects of combining industrialization in economically interdependent countries creates the international one. The first pattern of flying geese formation is a sequence of imports $(\mathrm{M}) \rightarrow$ domestic production $(\mathrm{P}) \rightarrow$ exports $(\mathrm{X})$. In the graphic presentation there are three time-series curves for a particular industry with the time dimension on the horizontal axis. The curve that is the closest to the origin of the set of coordinates represents imports of the product group, then appears domestic production curve, and the third one presents its exports. The vertical axis denotes value of imports, production and exports, respectively (Akamatsu, 1962). They create the import-production-export sequence, and they all rise and fall resembling an inverted $\mathrm{U}$ or $\mathrm{V}$-shaped formation. In nutshell, three curves together characterize the level of competitiveness of the relevant industry in a given country. The pattern displays how to substitute imports (IS) by promoting exports (EP). The second pattern expresses a sequence of product and industrial development from the obsolete industry through mature one up to the modern industries that are drivers (engines) of growth. It reflects the process of structural upgrading. The third pattern presents a hierarchy of economies at different stages of advancement (Akamatsu, 1962).

Although in times of Akamatsu foreign direct investment was not seen as meaningful factor of economic growth, he appreciated the significance of foreign impact of technology and knowledge for economic development that help emerge domestic production. It should also be added that original version of the model does not take regional integration process into consideration, either.

\section{THE THEORETICAL EVOLUTION OF THE ‘FLYING GEESE’ MODEL}

The mechanism, that dominates today's discourse, relies on the subsequent relocation of industries from advanced to developing countries during the latters' catching-up process. It was also regarded as the economic theory of an essential Japan's economic assistance to developing countries (Okuda, 2002). The major driver in the model is the technological development due to increasing labour costs that makes the "leader's imperative for internal restructuring" (Kasahara, 2004, p. 10) as its own income rise and it moves into newer, more capital-intense, technologies. This is the process by which technology and know-how become obsolete and are passed down the chain of latecomers' economies.

In academic discourse it is often underlined that Akamatsu's flying geese model does not rest on changes in relative competitiveness due to different resources but it is the result of 'demand linkages' and 'complementarities' of various products.

Seen from the perspective of international aspect of FGP, national policies may speed up the advancement, and even change the initial sequence of countries in the flying geese order.

Some scholars claim (e.g. Korhonen, 1994) that FGP was the precursor of the product cycle theory (PCT) developed by Raymond Vernon in the 1960s (Vernon, 1966). It should be remembered that Vernon's product cycle theory stems from microeconomic point of view in which a particular company makes decision on the location of its production facilities. It is helpful to explain issues of choice between the foreign trade and foreign direct investment as well as cooperation between economies of different production structures. Vernon distinguishes three stages of the product cycle, i.e. new product (innovation), maturing product, and standardized product. New product or process, usually the high income product and labour-saving process, are manufactured in the USA and exported to the other advanced countries. In the mature phase they are also exported to less developed countries, and when the product (process) reaches the stage of standardization, its production location is transferred from the most advanced country (the USA) first to other industrialized countries, and then to the less developed economies (Vernon, 1966). A producer - inventor first exploits its domestic market, and then conquers foreign markets of advanced econo- 
mies. When markets get larger and larger and the commodity with its associated technology is refined and standardized, foreign companies are encouraged to imitate and produce the same product to fulfil domestic demand, and eventually to take up exports. Here outward foreign direct investment is supposed to replace export (Kasahara, 2004).

At the first sight the descriptive results of both theories seem to be similar, but the major difference between them is the fact that the flying geese model focuses on sequential development of industries in less advanced countries, while the product cycle theory observes the location of production of a given product during its life cycle. What is more, FGP considers the innovation of new products in leader countries as exogenously given, and in the product cycle theory each economy's technological level is given and static (Schröpppel, Nakajima, 2002).

Vernon's PCT encouraged Akamatsu and his students, i.e. Kioyshi Kojima and Terutomo Ozawa to develop flying geese paradigm into modern versions. Japanese academics were the first who incorporated the different foreign activities of transnational companies, including FDI, into regional integration problem, mainly in the Pacific region. Modern FGP focuses on regionally contextualized transformation of national economies, rather than on the strategic behaviour of large firms considered by PCT. In this regard some theorists deal with the FGP as a derivative of what may be named the industry (life) cycle theory (Kasahara, 2004).

At the present time academics' mindsets are influenced by Kojima's concept of "catching-up product cycle" which is the contemporary interpretation of the flying geese paradigm (Kojima, 2000). First Kojima contrasts Japanese view (Akamatsu) with Vernon's approach, then incorporates microeconomic aspects into macroeconomic framework of the factor proportions theory (neoclassical Heckscher-Ohlin theorem). Such an approach is often named as "westernization" of FGP (Schröpppel, Nakajima, 2002 and Kasahara, 2013). Both, Kojima's reinterpretation of FGP and Vernon's theory are formulated from the perspective of developed economies.

Kojima as the first economist integrated the notion of foreign direct investment into the flying geese paradigm, intertwining periods of imports, production and exports of consumer goods in backward countries with periods of their imports, production and exports of capital goods (Kojima, 2000). He also attempted to identify the attributes of two types of FDI i.e. pro-trade (the Japanese type - complements) and anti-trade (the American type - substitutes) (Kojima, 1973 and 1977). Other than trade-oriented investments, Japan's overseas investments were initially (i.e. at the turn of the 1950s and the 1960s) allocated for exploitation of natural resources in resource-abundant countries or manufacturing labour-intensive products in labourabundant infant industrialised countries. Most of production from the first type of FDI was shipped back to Japan, while the manufactures from the second type were also exported back to Japan and to third-country markets. Intraindustry trade is tend to be identified with pro-trade FDI that is described in international economics manuals in two basic types. The horizontal intraindustry two-way trade occurs within a differentiated group of final products which is typical for a monopolistic market structure. The vertical intraindustry type is trade within the same industry, encompassing both intermediate goods exported by one country and final goods imported from the other one. Intraindustry trade, in particular the horizontal type of trade, does not reflect comparative advantages because the monopolistic competition theory of trade assumes the same labour/capital ratio (Krugman, Obstfeld, 2005). If FDI happens under such circumstances, trade might be replaced by local production in host countries. Substitutes and anti-trade FDI are consequences. Since the vertical type of intraindustry trade dominates nowadays it requires the new division of labour brought about by intra-firm factor movements, and created by FDI. Complements and pro-trade FDI are consequences.

The American FDI was aimed mostly to produce relatively technology-based, and capital-intensive products for local, i.e. host markets (Kojima, 1977). 
Regarding of the pattern of trade between countries in terms of relative differences in their factor endowments, but without any factor movement, capital transfer moves from a capital-abundant economy to a capital-scarce one in search of a higher marginal rate of return when the latter impedes the importation of capital-intensive goods from the former. Mundell was the first who described the substitution case of trade and capital factor movement, and his analysis predicted the immense inflow of the American FDI into Europe after the establishment of the European Economic Community in 1958 (Mundell, 1957). The EEC set up the discriminatory tariffs inducing American investments. Mundell claims that in the capital-receiving country, the capital inflow causes a change in equilibrium production point shifting it in such a direction that a capital-intensive industry (i.e., that country's comparatively disadvantaged industry) expands, while a less capital-intensive industry (i.e., that country's comparatively advantaged industry) contracts. In the home capital country the opposite phenomenon is perceived (Mundell, 1957). As a result, the foundation for commerce (i.e., the existing pattern of comparative advantage between the two countries) is in the end eliminated by capital movement (a case of substitution) (Ozawa, 2007).

Having adopted H. Johnson's (1972) definition of capital movement in the form of FDI ("the essence of direct foreign investment is the transmission to the 'host' country of a 'package' of capital, managerial skill, and technical knowledge"), Kojima recognized that the essence of FDI is not so much capital movement per se in neoclassical sense as knowledge transplantation that is mostly industry-specific (Ozawa, 2007).

Ordering Kojima's contribution to the extension of FGP and the contemporary role of FDI in catchingup process that can be adopt and foster to explain regional integration it is worth mentioning that he constructed, in fact, three models (Kojima, 2000):

Model I: (diversification and rationalisation of industries) in which the accumulation of physical and human capitals causes the economy to diversify first to more capital-intensive strategic industries and next to rationalise them so as to implement more efficient manufacturing methods. Kojima treats the model as the first of the theoretical pillars for the FGP (Kojima, 2000, p. 376);

Model II: (pro-trade-oriented foreign direct investment) in which the regional transmission of growth has been assisted by the "pro-trade-oriented" FDI device, that enables country's comparatively disadvantageous production to be transplanted onto a host country in such a way as to strengthen the latter's comparative advantage. Conjoining Akamatsu's basic model and Kojima's model II a result is the "FDI-led growth", and may be stylized as:

\begin{tabular}{|c|c|c|c|c|c|c|c|c|c|}
\hline M & $\longrightarrow$ & inward FDI & $\rightarrow$ & $\mathrm{P}$ & $\rightarrow$ & $\mathrm{X}$ & $\rightarrow$ & outward FDI & $\rightarrow$ \\
\hline \multicolumn{6}{|c|}{ Host country's viewpoint } & & \multicolumn{3}{|c|}{ Home country's viewpoint } \\
\hline
\end{tabular}

$\mathrm{M}, \mathrm{P}, \mathrm{X}$ - as above, $\mathrm{M}$ - reverse imports

So called "full circle model" is an evolutionary depiction of catching-up in, and next shedding of, an industry as a certain less advanced country successfully moves in flying geese formation from the low valueadded to higher value-added fabrication. Moreover, it should be mentioned that host country's part of the circle may occur instantly, if the initial imports can be bypassed by greenfield FDI that sets up local production which might be sold both in domestic market and abroad. Summing up, such a pro-trade oriented FDI constructs the second theoretical pillar for FGP.

Kojima's full circle model seems to be applicable to investigate alignment of countries of the EU since the modified sequence thrives in open economy environment, in favourable climate for FDI where inward and outward flows are unrestricted, and the market is highly liberalised, i.e. it regulates and coordinates economic activities as well as resource allocation. 
Model III: (agreed specialisation) is the third theoretical pillar of FGP that is presented as an effective measure to increase intraindustry trade in an integrated region. It is important for integration process while the structure of industries and exports in each country become more and more alike. Hence, intraindustry trade promotion may help avoid trade conflicts and foster regional integration (Kojima, 2000, p. 386).

The last outstanding theorist whose contribution to FGP is worth mentioning is T. Ozawa. In regard to the interindustry pattern of FGP he separates five stages as a "flight map" for follower geese to be guided in their drive to catch up on growth. Ozawa also assigned to these stages surnames of corresponding economists or entrepreneurs. Stage 1 is the endowments driven or labour-intensive stage (e.g. textiles or rural sector), identified with Heckscher-Ohlin; Stage 2 is a physical scale-driven one (e.g. capital-intensive or natural resource processing) almost homogenized, and identified with Adam Smith; Stage 3 is consumer-oriented one (e.g. clothing but also vehicles) which is widely differentiated, and identified with Henry Ford; Stage 4 concerns R\&D-based sectors (e.g. computers), and represented by Joseph Schumpeter; Stage 5 deals with information technology (internet-based information services), and its 'face' is Marshall McLuhan (Ozawa, 2009). Ozawa stresses that each stage of development demands different preparatory measures, institutions and strategies, so the FDI-led take-off applies in labour-intensive emerging economies, then higher stages are built on capital-intensive, and eventually on knowledge based technologies (Ozawa, 2012).

\section{THE ‘EUROPEIZATION’ OF THE ’FLYING GEESE` MODEL}

The 'flying geese' paradigm has been evolving as a model for many decades incorporating new products and industries that correspond to relevant level of technology, new phenomena, governmental policy, etc. Hence, it is worth looking at, whether a FDI phenomenon can be applied to interpret regional integration between economies of various development levels in Europe. Being aware of a broad scope of issues the model encompasses, it is necessary to choose an exact subject of investigation which will enable to achieve an assumed purpose. As an empirical method to assess the usefulness of FGP in the EU, presuming that FDI might play a significant role in upgrading economies, a comparative case study has been taken. It relies on assumption that the UE-12 countries (former Common Market at the turn of 1970s and 1980s) are the leaders of growth in the "flying geese formation", and that next comers to the EU are less advanced (followers). Therefore, two countries of a certain likeness have been selected, which joined the 'formation' in different periods. The research task is to answer the question whether they were catching up the leaders' group (EU-12) in the process of regional integration, i.e. strictly expressing whether they were imitating Kojima's model II by use of FDI.

In order to contemplate the model under the EU circumstances Spain and Poland have been selected as countries of a resemblance as regards, not only, geographical (land area) and demographical (population) characteristics in the year of accession (1986 and 2004, respectively). A visible convergence of some basic economic indicators confirms an appropriate relevance of the countries selection (Table 1 and Table 2). Relatively similar economic level of both countries in the year of accession to the Community and ten years after (measured by a value of GDP per capita and comparable share of foreign trade in GDP), and nearly twenty years of time lag regarding the year of their accession does not allow forgetting about Poland's backwardness. Years from Spain's accession to Maastricht $(1986$ - 2001) are called the "the golden years" of Spanish membership since it was the period of the Spanish government's efforts to formulate the European policy aimed at maximizing both the internal and external benefits resulting from integration process (Powell, 2001). Moreover, the first decade for Spain was much more favourable taking a business cycle into account than for Poland (a long lasting crisis then a slowdown not only in the European economy). 
Nevertheless Poland improved GDP per capita in PPS for the EU-28=100 more than by one third while Spain was worse off though new comers in 2004 were less advanced that lowered the basis of the indicator.

Looking for regularities and relationships between FDI, foreign trade and development, foreign direct investment stocks (position) are assumed to be a better measure of the total level of direct investment at a given point in time, usually at the end of a year. The next reason of the above choice is that stocks create stable and long-lasting business links between economies. The outward FDI stock is the value of the resident investors' equity in and net loans to enterprises in foreign economies. The inward FDI stock is the value of foreign investors' equity in and net loans to enterprises resident in the reporting economy. FDI stocks are measured in USD and as a share of GDP (Table 2).

Table 1

Comparative statistics of Spain and Poland's likeness

\begin{tabular}{|c|c|c|c|c|}
\hline \multirow{2}{*}{$\begin{array}{l}\text { Characteristics } \\
\text { Year of accession to the EU }\end{array}$} & \multicolumn{2}{|c|}{ S P A I N } & \multicolumn{2}{|c|}{ P O LAN D } \\
\hline & 1986 & Ten years after & 2004 & Ten years after \\
\hline Population in millions ${ }^{1}$ & 38.543 & 39.260 & 38.620 & 36.620 \\
\hline Land area in $\mathrm{km}$ & 500210 & & 306210 & \\
\hline GDP per capita US dollars & $6,504.1$ & $16,236.8$ & $6,640.0$ & $14,342.9$ \\
\hline $\begin{array}{l}\text { GPD per capita } \mathrm{EU}=15(\%) \\
\text { GPD per capita in PPP EU-28 }=100\end{array}$ & $\begin{array}{l}72.5 \\
100^{3}\end{array}$ & $\begin{array}{c}81 \\
91^{4}\end{array}$ & 49 & 68 \\
\hline Annual average growth rates of real GDP & $2.9^{5}$ & $3.2^{6}$ & $5.7^{7}$ & $3.9^{8}$ \\
\hline $\begin{array}{l}\text { Average GDP growth rate in the first decade } \\
\text { in the EU }\end{array}$ & \multicolumn{2}{|c|}{2.98} & \multicolumn{2}{|c|}{3.95} \\
\hline $\begin{array}{l}\text { Average GDP growth rate of the European } \\
\text { Community (EU-27) in the relevant decade }\end{array}$ & \multicolumn{2}{|c|}{$2.46(1986-1996)$} & \multicolumn{2}{|c|}{$1.1(2004-2014)$} \\
\hline Exports as percentage of GDP & 18.3 & 23.1 & 34.6 & 47.4 \\
\hline Imports as percentage of GDP & 17.1 & 23.2 & 37.2 & 46.2 \\
\hline Market integration indicator ${ }^{6}$ & $1.3^{6}$ & 1.0 & 2.7 & $0.7^{9}$ \\
\hline Market integration indicator in the EU & & 0.7 & $\begin{array}{l}1.1 \\
0.9\end{array}$ & $\begin{array}{l}2.8 \\
2.4\end{array}$ \\
\hline
\end{tabular}

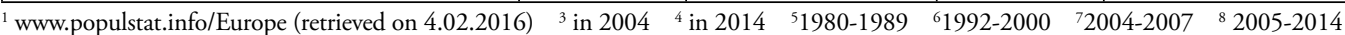

${ }^{9}$ in $2012{ }^{6}$ Market integration indicator or FDI intensity is an average value of inward and outward FDI flows divided by GDP. The index measures the intensity of investment integration within the international economy. (Spain in 1993)

Source: UNCTAD database, Eurostat database, database of the National Bank of Poland, World Bank (retrieved on several days from January to March, 2016).

The first indicator describing the role of FDI in economy is its position as percentage of GDP (Table 2). The UE-15 up to 2004, afterwards EU-27 had been a net FDI sender over the entire period and what is more, its percentage share in GDP had been increasing gradually up to $60 \%$ as regards outward and up to $50.6 \%$ as regards inward. In contrary, both Spain and Poland are still net receivers, and percentage shares of FDI in GDP are lower as compared with the UE, Poland's in particular, in respect to outward position $(10.7 \%$ versus $48.8 \%$, respectively). Taking the statistics of the first ten-year period in the UE, studied countries may be comparable only from outward position viewpoint (3\% in Spain and $1.3 \%$ in Poland). Poland took much greater advantage from inward FDI at the year of accession (34.4\%) than Spain (12.7\%), and so did after 10 years (17.9\% vs. $48.8 \%)$. 
Coming to the point of cognitive task, in Koijma's model II imports is followed by inward FDI presumed as "led growth" factor. Over ten years Spain's major imports partners had not changed meaningfully, however trade relationships had been enhanced with the EU economy (Table 3).

Table 2

FDI stocks as percentage of GDP for the EU, Spain and Poland

\begin{tabular}{|c|c|c|c|c|c|c|}
\hline & \multicolumn{2}{|c|}{ The European Union } & \multicolumn{2}{c|}{ Spain } & \multicolumn{2}{c|}{ Poland } \\
\hline year & outward & inward & outward & inward & \multirow{2}{*}{ outward } & inward \\
\hline 1985 & 10.7 & 8.3 & 3.0 & 12.7 & & \\
\hline 1995 & 15.4 & 17.6 & 5.7 & 17.9 & & 34.3 \\
\hline 2004 & 41.2 & 36.6 & 27.0 & 39.0 & 1.3 & 48.8 \\
\hline 2013 & 60.0 & 50.6 & 43.5 & 52.7 & 10.7 & 4 \\
\hline
\end{tabular}

Source: OECD (2014), OECD International Direct Investment Statistics 2014, OECD Publishing http://dx.doi. org/10.1787/idis-2014-en (referred on 1.02.2016)

Table 3

Imports structure broken down by main Spain's partners (percentage share) in 1986 and 1996

\begin{tabular}{|l|c|c|c|}
\hline & 1986 & 1996 \\
\hline EU-15 & 53.5 & EU-15 & 66.4 \\
\hline Germany & 15.1 & France & 17.8 \\
\hline France & 11.8 & Germany & 14.9 \\
\hline USA & 9.9 & Italy & 9.6 \\
\hline United Kingdom & 7.7 & United Kingdom & 8.3 \\
\hline Italy & 7.3 & Benelux & 7.5 \\
\hline Japan & 4.9 & USA & 6.3 \\
\hline
\end{tabular}

Source: Own calculation based on Institutio National Estadistica Annuario 1987, 1997, www.ine.es/fnebaseweb (retrieved on $15.02 .2016 ; 24.02 .2016$ )

- Spain's imports were based in both considered years on food products, raw materials including fuels, chemical industry, machinery and transport equipment (Table 4). Essential changes might be observed in raw materials (decreased strictly by a half) and in transport sector (nearly doubled). Comparing both imports structures, i.e. broken down by partners and by commodities with respective FDI inward structures (Table 5 and Table 6 ) the following findings might be mentioned:

- Spain's internationalisation (imports and inward FDI) focused definitely on developed countries, mainly within the EU.

- Over studied ten-year period the percentage share of the EU rose significantly (as much as 13.1 percentage points as considers imports and by over 2.5 percentage points as considers inward FDI).

- Relative indicators of similarity structure, calculated as $Z=\frac{\sum_{i}^{n} \min (W i)}{\sum_{i}^{n} \max (W i)}$, 
where: $Z$ - Relative Indicator of Similarity Structure, which $Z \in\langle 0,1\rangle$, the closer to 1 the higher level of similarity structure, $\mathrm{W}_{\mathrm{i}}$ - indicators of structure with reference to imports structure as well as to FDI, display that similarity structure is almost the same and recognized as high (0,683 as regards imports and 0,638 as regards FDI).

- Imports of machinery and transport equipment corresponded with FDI inward stock in manufacturing and huge increase of services such as real estate and business activities.

Spain's accession to the EU began a long period of expansion of the Spanish economy driven mostly by the huge increase of external financing. Decomposition of sources of the Spanish boom period prepared by use of the QUEST model shows that the easy access to international financing with low interest rates had meaningful effects on business investment (European Commission, 2012). Moreover, the OECD FDI Regulatory Restrictiveness Index that evaluates the restrictiveness of a country's FDI procedures covering such as: foreign equity restrictions, screening or approval mechanisms, restraints on key foreign employment, operational restrictions, has been among the lowest values for Spain, i.e. 0.021versus OECD's average 0.076 ( $0<\mathrm{RRI}<1$; 0 means open economy; 1 means closed economy) (OECD, 2014).

The result was the strengthening of the EU partners' position in exports (Table 7), above all Spain's geographical neighbours (France, Italy and Portugal). However, the exports commodity structure did not change radically over ten years (the relative indicator of similarity structure $\mathrm{Z}=0.718$, i.e. of high level), but it corresponded to moderate changes in FDI outward structure $(\mathrm{Z}=0.538)$ over the given period (Table 6). The dominating share of machinery and transport industries in exports mainly to the EU economies had been transformed into increase in outward FDI to Latin America and the Caribbean (Table 8). The EU lost its leadership in outward FDI (41.2\% and 36.6\%, respectively).

Table 4

Spain's imports and exports structure broken down by commodities in 1986 and 1996

\begin{tabular}{|c|c|c|c|c|}
\hline \multicolumn{2}{|c|}{ IMPORTS } & \multicolumn{2}{c|}{ EXPORTS } \\
\cline { 1 - 4 } 1986 & 1996 & Group of commodity & 1986 & 1996 \\
\cline { 4 - 5 } & 12.7 & Food products & 16.9 & 15.7 \\
\hline 22.0 & 10.7 & Raw materials including fuels & 6.6 & 3.2 \\
\hline 9.4 & 9.3 & Chemical industry & 4.1 & 6.1 \\
\hline 3.6 & 5.0 & Plastics and rubber & 5.5 & 4.7 \\
\hline 1.7 & 1.0 & Furs, feather, glassware & 1.1 & 1.1 \\
\hline 1.3 & 1.1 & Timberland products & 3.3 & 2.3 \\
\hline 2.5 & 2.9 & Paper industry & 4.7 & 2.6 \\
\hline 3.3 & 5.0 & Textile industry & 25.6 & 4.3 \\
\hline 28.2 & 30.5 & Metal products, machines, and electric equipment & 17.4 & 25.0 \\
\hline 8.4 & 15.1 & Transport & 0.9 & 25.8 \\
\hline 5.7 & 3.1 & Optics & 3.4 & 1.2 \\
\hline 1.0 & 3.5 & Miscellaneous products & 9.5 \\
\hline
\end{tabular}

Source: Own calculation based on Institutio National Estadistica Annuario 1987, 1995, 1997, www.ine.es/fnebaseweb (retrieved on 15.02.2016; 26.02.2016) 
Summing up Spain's case from Kojima's model II viewpoint, it may be concluded that combined analysis of foreign trade and FDI broken down by main partners, commodities and economic activities in two marginal years of the first decade confirmed to some extent a sequence of phenomena taking place in "flying geese" formation. Spain developed the economy by means of imports of machinery and transport equipment industries followed and reinforced by inward FDI in manufacturing, real estate, business activities and information from developed countries, mainly from the EU. Afterwards, products of alike commodity groups were exported to practically the same group of developed countries, mainly Spain's neighbours. Finally, outward FDI had been positioned mostly in less developed countries displacing so far partners.

Today, Spain is Europe's third economy for outward FDI as a share of GDP and second for inward FDI. Integration in the European Union also played an important role in drawing FDI, as it made Spain significantly more attractive as a location for multinationals, by ensuring more open and competitive policies in greater harmony with those of its EU partners (Myro R., 2015).

Table 5

Spain's FDI (stock) inward position in 1986 and 1996 broken down by percentage share of main partners

\begin{tabular}{|l|c|l|c|}
\hline \multicolumn{2}{|c|}{1986} & \multicolumn{2}{c|}{1996} \\
\hline EU-15 & 68.24 & EU-15 & 70.9 \\
\hline United Kingdom & 23.7 & France & 18.0 \\
\hline Germany & 24.9 & Germany & 16.7 \\
\hline EFTA & 11.7 & Benelux & 23.3 \\
\hline France & 8.2 & United Kingdom & 9.9 \\
\hline USA & 7.6 & Italy & 8.5 \\
\hline Netherlands & 6,1 & Latin America & 5.4 \\
\hline Japan & 4.3 & USA & 4.2 \\
\hline
\end{tabular}

Source: Own calculation based on OECD. (2000), International Direct Investment Statistics Yearbook 1999, OECD Publishing, Paris. DOI: http://dx.doi.org/10.1787/direct_invstat-1999-en-fr.

Table 6

Sectoral breakdown of Spain's FDI inward and outward position in 1986 and 1996 (percentage share)

\begin{tabular}{|l|c|c|c|c|}
\hline & \multicolumn{2}{|c|}{ Inward } & \multicolumn{2}{c|}{ Outward } \\
\hline & 1987 & 1996 & 1987 & 1996 \\
\hline Primary & 1.8 & 0.9 & 5.9 & 8.2 \\
\hline Manufacturing & 52.6 & 47.9 & 17.4 & 28.1 \\
\hline Electricity, Gas and Water & 0 & 0.1 & 0 & 2.9 \\
\hline Construction & 0.2 & 0.9 & 0.2 & 0.8 \\
\hline $\begin{array}{l}\text { Wholesale and Retail Trade; Repair of Motor Vehicles and } \\
\text { Motorcycles, Hotels and Restaurants }\end{array}$ & 18.9 & 16.6 & 14.8 & 12.9 \\
\hline Transportation, Storage and Communication & 0.6 & 1.6 & 3.0 & 4.9 \\
\hline Financial and Insurance Activities & 24.4 & 9.6 & 58.5 & 28.4 \\
\hline Real Estate Renting \& Business Activities Information & 0.9 & 20.0 & 3.2 & 13.6 \\
\hline
\end{tabular}

Source: Own compilation based on OECD. (2000), International Direct Investment Statistics Yearbook 1999, OECD Publishing, Paris. DOI: http://dx.doi.org/10.1787/direct_invstat-1999-en-fr. 
Exports structure broken down by Spain's main partners (percentage share) in 1986 and 1996

\begin{tabular}{|l|c|l|c|}
\hline & 1986 & & 1996 \\
\hline EU-15 & 62.3 & EU-15 & 70.9 \\
\hline France & 18.0 & France & 21.7 \\
\hline Germany & 11.7 & Germany & 14.6 \\
\hline United Kingdom & 9.1 & Italy & 13.3 \\
\hline \multicolumn{1}{|c|}{ USA } & 9.1 & Portugal & 8.8 \\
\hline Italy & 7.9 & United Kingdom & 8.3 \\
\hline Latin America & 5.4 & Latin America & 5.4 \\
\hline Japan & 4.9 & USA & 4.2 \\
\hline Middle East & 4.7 & Middle East & 2.4 \\
\hline
\end{tabular}

Source: Own calculation based on Institutio National Estadistica Annuario 1987, 1997, www.ine.es/fnebaseweb (retrieved on 15.02.2016; 24.02.2014)

Table 8

Spain's FDI (stock) outward position in 1986 and 1996 broken down by geographical destination (percentage share of main partners)

\begin{tabular}{|l|c|l|c|}
\hline \multicolumn{2}{|c|}{1986} & \multicolumn{2}{c|}{1996} \\
\hline EU-15 & 41.2 & EU-15 & 36.6 \\
\hline USA & 29.8 & Latin America and Caribbean & 47.3 \\
\hline France & 18.3 & USA & 8.5 \\
\hline OPEC & 16.3 & Germany & 5.9 \\
\hline Portugal & 5.4 & United Kingdom & 3.9 \\
\hline Netherlands & 1.0 & Benelux & 3.8 \\
\hline Benelux & 0.7 & Ireland & 3.7 \\
\hline EFTA & 0.2 & Italy & 2.6 \\
\hline
\end{tabular}

Source: UNCTAD FDI OECD. (2000), International Direct Investment Statistics Yearbook 1999, OECD Publishing, Paris. DOI: http://dx.doi.org/10.1787/direct_invstat-1999-en-fr

Poland, in turn, accessed the EU in 2004, being at a similar level of economic advancement as Spain roughly twenty years before. The relatively good performance of the Polish economy over the first decade made the Polish market pretty attractive for the inflow of FDI. According to the World Bank Poland seems to be on the brink of its new "golden age" (World Bank, 2015). With the accession to the UE business climate in Poland had been improving (the FDI Regulatory Restrictiveness Index reached 0.072 in 2012 as compared with an average 0.025 in the EU and 0.076 in OECD). 
Breakdown of Poland's imports by geographical destination in 2004 and 2014 (main partners' percentage shares)

\begin{tabular}{|c|c|c|c|}
\hline \multicolumn{2}{|c|}{2004} & \multicolumn{2}{|c|}{2014} \\
\hline EU-25 & 75.8 & EU-28 & $68.9^{1}$ \\
\hline Germany & 25.0 & Germany & 23.0 \\
\hline Italy & 7.8 & Russia & 9.8 \\
\hline Russia & 6.9 & China & 9.2 \\
\hline France & 6.5 & Italy & 5.3 \\
\hline China & 4.6 & Netherlands & 4.1 \\
\hline Czech Republic & 3.8 & France/Czech Republic & 3.9 \\
\hline
\end{tabular}

Source: Own calculation based on http://ec.europa.eu/eurostat/web/international-trade/data/main-tables

Poland's imports were based on the EU economies over the examined period, despite the slight decline (varied from three-quarters to over two-thirds), and on an outstanding share of Germany as well as a remarkable share of Russia (Table 9). The EU partners supplied machinery, transport equipment and other fabricated goods necessary to an enormous economic transformation (Germany and other developed countries) and raw materials including fuels (Russia) (Table 10), what was confirmed by a very high level of the Relative Indicator of Similarity Structure $(Z=0.906)$ as regards geographical origins of imports.

The analysis made from the Kojima's full circle model viewpoint sheds light on the following findings:

- The percentage share of imports in GDP rose as much as nearly 13 percentage points over 2004-2014, and FDI inward stocks in GDP ranged from $34.4 \%$ to $48.8 \%$ (Table 2), i.e. increased even more (by 14.5 percentage points). Inward FDI stocks had been allocated in manufacturing, mainly, though the percentage share of the activity declined by 8.5 percentage points.

- The leading investors came from the EU (their percentage share varied insignificantly from $94.2 \%$ in 2004 to $92.0 \%$ in 2014 - Table 11). Germany as the greatest trade partner remained the second largest investor. Poland having an economy of intrinsic interest attracted new investors from Luxemburg and Spain in 2014. The latter country may prove a change of internal tier of the "flying geese formation" with respect to less developed country.

- The Relative Indicator of Similarity Structure referring to sectoral breakdown of inward FDI points out a high similarity of compared structures $(\mathrm{Z}=0.878)$, however FDI inward position in real estate renting and business activities doubled.

- Finally, imports streams of manufactured goods were followed by inward FDI flows, oriented on manufacturing and modern services, and both originated from similar countries. 
Poland's imports and exports broken down by commodities in 2004 and 2014 (percentage share)

\begin{tabular}{|c|c|c|c|c|}
\hline 2004 & 2014 & \multirow{2}{*}{ Group of commodity } & 2004 & 2014 \\
\cline { 4 - 5 } & & & \multicolumn{2}{c|}{ Exports } \\
\hline 5.2 & 8.0 & Food, drinks, tobacco & 8.2 & 12.3 \\
\hline 3.8 & 3.7 & Raw materials & 2.7 & 2.7 \\
\hline 9.2 & 10.7 & Mineral fuels, lubricants and related materials & 5.5 & 4.1 \\
\hline 14.2 & 14.7 & Chemicals and related products & 6.5 & 9.1 \\
\hline 38.7 & 34.3 & Machinery and transport equipment & 38.8 & 38.0 \\
\hline 29.0 & 28.5 & Other manufactured goods & 38.4 & 33.7 \\
\hline
\end{tabular}

Source: Own compilation based on http://ec.europa.eu/eurostat/web/international-trade/data/main-tables (23.02.2016)

Table 11

Poland's FDI (stock) inward position broken down by percentage share of main partners in 2004 and 2014

\begin{tabular}{|l|c|l|c|}
\hline \multicolumn{2}{|c|}{2004} & \multicolumn{2}{c|}{2014} \\
\hline UE-25 & 94.2 & UE-27 & 92.0 \\
\hline Netherlands & 23.6 & Netherlands & 17.2 \\
\hline Germany & 16.6 & Germany & 16.3 \\
\hline France & 13.4 & Luxemburg & 13.0 \\
\hline Austria & 5.0 & France & 12.0 \\
\hline Sweden & 4.1 & Spain & 7.0 \\
\hline
\end{tabular}

Source: Own calculation based on the National Bank of Poland database

Poland's exports as percentage of GDP increased essentially over 2004 - 2014 (as much as nearly 13 percentage points - Table 1) and faster than the outward FDI stock (by slightly over 9 percentage points Table 2). The EU countries remained the major destination ( $80.3 \%$ versus $74.8 \%$, respectively), Germany maintained its dominant position as the Poland's trade partner regardless a five-percentage-point decline, and Russia was the only outsider among the major partners (Table 13). Others countries' share was roughly alike (ranged from nearly $4 \%$ to $6.5 \%$ ), so the position of a particular country was irrelevant. Exports structure broken down by commodities actually had not changed since major groups were machinery, transport equipment and other manufactured goods (Table 10), thus it resulted in a very high level of the Relative Indicator of Similarity Structure $(Z=0.913)$. Mixed indicators, i.e. indicators finding out the relative similarity structure of exports-imports commodity structure in surveyed years ( $Z=0.777$ in 2004 and $Z=0.765$ in 2014) point also out a high value of resemblance (a dominant of industrial goods in both directions), though they are lower in comparison to indicators calculated separately for imports (exports) because of the share of mineral fuels in imports, primarily.

Before accession to the EU Poland's outward FDI stock was minor (1.3\% of GDP - Table 2) and was derived from trade-supporting activities in key markets for many years (Germany, Italy, France, United Kingdom). They were largely commercial in nature and were intended to support exports in the form of 
commercial offices and retail outlets. Therefore, the outflow of domestic capital did not substitute for exports significantly (Buczkowski, 2013).

A current geographical destination of the Polish FDI indicates that they differ from traditional direct investment in which a lasting interest implies the existence of a long-term relationship between the direct investor and the enterprise, and an investor's significant influence on the management of the enterprise play a specific role in a host country's real economy. The Polish transactions have still represented optimization type, mainly, and major host countries, that cover over $80 \%$ of outward FDI, are mostly transit countries (Table 14).

An outstanding case is the Polish FDI made in Czech Republic, where in contrast to Cyprus, Luxemburg, Netherlands and Switzerland, a significant portion of the Polish direct investment assets stems from a desire to use the special purpose entities for both tax and operation optimization of transactions. Investment in Czech Republic is often made without mediation of the countries listed above (NBP, 2015).

The Polish outward FDI has had the tendency to increase in parallel with its economic growth. Investment in service sector outweighs suggestively manufacturing one, and the latter prevail in the neighbour countries (the Czech Republic, Germany, Lithuania). The increase in primary sector might correspond to intensive growth of CIS in destination structure. This phenomenon may be the beginning of the trend towards the "full circle model".

Table 12

Sectoral breakdown of Poland's FDI inward and outward position in 2004 and 2014 (percentage share)

\begin{tabular}{|l|c|c|c|c|}
\hline & \multicolumn{2}{|c|}{ inward } & \multicolumn{2}{c|}{ outward } \\
\hline & 2004 & 2014 & $2004^{1}$ & 2014 \\
\hline Primary & 0.7 & 0.8 & 0 & 5.0 \\
\hline Manufacturing & 37.9 & 29.4 & 18.0 & 14.1 \\
\hline Electricity, Gas and Water & 3.6 & 3.2 & 0.2 & -4.7 \\
\hline Construction & 1.9 & 4.6 & 1.2 & -1.0 \\
\hline $\begin{array}{l}\text { Wholesale and Retail Trade; Repair of Motor Vehicles } \\
\text { and Motorcycles }\end{array}$ & 17.9 & 13.6 & 13.4 & 6.5 \\
\hline Transportation, Storage and Communication & 7.6 & 5.2 & 6.6 & 1.9 \\
\hline Financial Intermediation & 19.7 & 23.1 & 23.9 & 50.4 \\
\hline Real Estate Renting \& Business Activities, Information & 10.2 & 20.1 & 8.5 & 28.5 \\
\hline
\end{tabular}

${ }^{1}$ In 2004 non-classified services took $28.1 \%$

Source: Own calculation based on the National Bank of Poland database

Breakdown of Poland's exports by geographical destination in 2004 and 2014

(percentage shares of main partners)

\begin{tabular}{|l|c|l|c|}
\hline \multicolumn{2}{|c|}{2004} & \multicolumn{2}{c|}{2014} \\
\hline EU-25 & 2 & \multicolumn{1}{c|}{3} & 4 \\
\hline Germany & 80.3 & EU-27 & $74.8^{1}$ \\
\hline Italy & 28.0 & Germany & 23.0 \\
\hline
\end{tabular}




\begin{tabular}{|l|l|l|c|}
\hline \multicolumn{1}{|c|}{1} & \multicolumn{1}{|c|}{3} & \multicolumn{1}{c|}{} \\
\hline France & 6.0 & France & 5.6 \\
\hline United Kingdom & 4,9 & Czech Republic & 5.5 \\
\hline Czech Republic & 4.5 & Russia ${ }^{1}$ & 5.2 \\
\hline Russia & 3.9 & Italy & 4.5 \\
\hline Netherlands & 3.8 & Netherlands & 4.0 \\
\hline
\end{tabular}

${ }^{1} 2013$

Source: Own compilation based on: UNCTADSTAT (23.02.2016); atlas.media.mit.edu (29.02.1014)

Table 14

Poland's FDI outward position in 2004 and 2014 broken down by geographical destination (percentage shares of main partners)

\begin{tabular}{|l|c|l|c|}
\hline \multicolumn{2}{|c|}{2004} & \multicolumn{2}{c|}{2014} \\
\hline EU-25 & 54.8 & EU-27 & 71.4 \\
\hline Netherlands & 15.7 & Cyprus & 31.7 \\
\hline Switzerland & 14.5 & Luxemburg & 26.9 \\
\hline Germany & 11.2 & Switzerland & 12.0 \\
\hline Transition economies ${ }^{1}$ & 8.8 & Netherlands & 6.3 \\
\hline CIS $^{2}$ & 8.7 & Czech Republic & 4.2 \\
\hline Ukraine & 5.8 & Germany & 4.2 \\
\hline France & 5.7 & CIS & 3.5 \\
\hline Benelux & 5.2 & Lithuania & \\
\hline
\end{tabular}

${ }^{1}$ Transition economies are those of Bosnia and Herzegovina, Montenegro, Serbia, The FYR of Macedonia

${ }^{2}$ CIS includes countries such as Azerbaijan, Belarus, Kazakhstan, Moldova, Russian Federation, Tajikistan, Ukraine, Uzbekistan

Source: Own calculation based on Poland's National Bank database

\section{CONCLUSION}

Dynamic changes have been shifting the international system of forces and comparative advantages of countries and enterprises in the globalized economy over last decades. The European Union has evolved during this time, both quantitatively and qualitatively. Therefore, it is a challenge to verify practically a capability of existing theories to explain phenomena of contemporary international relations in "meta economy". Outcome of the comparative analysis indicates that foreign direct investment seems to be a key element of international economic integration. It is a crucial factor encouraging transfer of technology and know-how between economies and it fosters the host country to promote its products in markets abroad. Being also an additional source of funding FDI can be called the up-to-date driver for development.

In Spain international capital flows were the main engine that was pushing investment beyond its steady state until 2003. The analysis showed that in that case the full Kojima's model II could be observed.

Although Poland has transformed itself from a country of European periphery to a high-level income economy, a large productivity gap with top-performing EU countries still exists, and regional disparities within the country still prevail. Strengthening the business environment and promoting a cohesive regional development strategy are key actions in Poland's long-term competitiveness and productivity agenda. Taking 
"flying geese" paradigm into account a case of Poland hardly proves a sequence of interdependence described by "full circle model".

The study confirmed the correct choice of countries from the point of view of their suitability for 'Europeization' of the "flying geese" model, however a precise and complete answer seems to be obtained after a longer period, particularly for Poland, and deeper insight into an intraindustry interdependence.

\section{REFERENCES:}

Akamatsu K. (1962) "A Historical Pattern of Economic Growth in Developing Countries", Journal of Developing Economies, Preliminary Issue No.1, pp. 3-25.

Buczkowski B. (2013), "Poland's outward foreign direct investment", steconomiceuoradea.ro/anale/volume/2013/.../007.pdf "Doing Business in Poland in 2015", (2015), Report No. AUS7323, World Bank Group

European Commission (2012), "European Economy, Macroeconomic imbalances - Spain”, Occasional Papers No. 103 Johnson H. G. (1972), "Survey of Issues," in Drysdale P. (ed.), Direct Foreign Investment in Asia and the Pacific, Toronto, University of Toronto Press.

Institutio National Estadistica Annuario (1987, 1997), www.ine.es/fnebaseweb

Kasahara S. (2004), "The Flying Geese Paradigm: A critical study of its application to East Asian regional development", United Nations Conference on Trade and Development, Discussion Papers, No. 169, pp. 1-25

Kasahara S. (2013), "The Asian Development State and the Flying Geese Paradigm”, United Nations Conference on Trade and Development, Working Papers, No. 213, pp. 1-26

Kojima K. (1973), “The Macroeconomic Approach to Foreign Direct Investment”, Hitotsubashi Journal of Economics, Vol. 14, No. 1, pp.1-21

Kojima K. (1977), “Transfer of Technology to Developing Countries - Japanese Type versus American Type”, Hitotsubashi Journal of Economics, Vol. 17, No. 2, pp. 2-14

Kojima K. (2000), "The "Flying geese" model of Asian economic development: origin, theoretical extensions, and regional policy implications", Journal of Asian Economics, No.11, pp. 375-401

Korhonen P. (1994)," The Theory of the Flying Geese Pattern of Development and its Interpretations", Journal of Peace Research, Vol. 31, No. 1, pp. 93-108

Krugman P. R., Obstfeld M. (2005), International Economics: Theory \& Policy, $7^{\text {th }}$ edition, Boston, Pearson/ Addison-Wesley

Kwan C.H. (1994) Economic Interdependence in the Asia-Pacific Region. Towards the Yen block, London, Routledge Myro R. (2015), "Foreign Direct Investment in Spain”, SEFO - Spanish Economic and Financial Outlook, Vol 4, No.1

Mundell R. A. (1957), "International Trade and Factor Mobility", American Economic Review No. 47, pp. 321-335

Narodowy Bank Polski (2015), „Zagraniczne inwestycje bezpośrednie w Polsce i polskie za granicą w 2014 roku”, Warszawa

OECD (2014), OECD International Direct Investment Statistics 2014, OECD Publishing http://dx.doi.org/10.1787/ idis-2014-en

OECD (2014), "Foreign direct investment" in OECD Factbook 2014: Economic, Environmental and Social Statistics, OECD Publishing, Paris

Okuda H. (2002), "Today's Problems in Developing Financing and Japan's Financial Assistance for Economic Development. Aiming at Knowledge-Based-Type Assistance", Technology and Development, JICA: Institute for International Cooperation No. 15, pp.5-10

Ozawa T. (2007), "Professor Kiyoshi Kojima’s Contributions to FDI Theory: Trade, Structural Transformation, Growth, and Integration in East Asia", Annual Conference of the Japan Society of International Economics (JSIE), at 
Nagoya University, Japan, October 14-15, 2006, academiccommons.columbia.edu/catalog/ac:108870 (referred on 23/01/2016)

Ozawa T. (2009), The Rise of Asia: The flying geese theory of tandem growth and regional Agglomeration, Cheltenham, U.K., Northampton USA, Edward Elgar

Ozawa T. (2012), "FDI, catch-up growth stages and stage-focused strategies”, Columbia FDI Perspectives, Perspectives on topical foreign direct investment, Vale Columbia Center on Sustainable International Investment, No. 70, pp. 1-3, www.voc.columia.edu (referred on 23/01/2016)

Powell Ch. (2001), "Fifteen years on Spanish membership in the European Union revisited", Paper presented at the conference, "From isolation to integration: 15 years of Spanish and Portuguese Membership in Europe," Minda de Gunzburg Center for European Studies, Harvard University, 2-3 November, http://aei.pitt.edu/9138/1/Powell.pdf (retrieved on 14/02/2016)

Schröppel C., Nakajima M. (2002), "The Changing Interpretation of the Flying Geese Model of Economic Development”, Deutsches Institut für Japanstudien No. 14, Munich, pp. 203-236

Vernon R. (1966), "International Investment and International Trade in the Product Cycle", The Quarterly Journal of Economics, Vol. 80, No. 2, pp. 190-207 